Egyptian Journal of Aquatic Biology \& Fisheries

Zoology Department, Faculty of Science,

Ain Shams University, Cairo, Egypt.

ISSN $1110-6131$

Vol. 24(4): 33 - 42 (2020)

www.ejabf.journals.ekb.eg

\title{
Some Fisheries and Biological Aspects of the Crayfish Procambarus clarkii (Girard, 1852) in the River Nile, Egypt
}

\author{
Walid Aly*, Alaa El-Far, and Mohamed A. Fetouh
}

Fisheries Biology Lab., Fisheries Division, National Institute of Ocean. \& Fish., Egypt.

*Corresponding Author: walid.soton@gmail.com

\section{ARTICLE INFO}

Article History:

Received: May 19, 2020

Accepted: June 4, 2020

Online: June 7, 2020

Keywords:

Procambarus clarkia

Crayfish

Harvestable size;

allometric growth;

sex ratio;

population structure

\section{ABSTRACT}

Procambarus clarkii, as an invasive species, has proved to have an adverse impact on the Egyptian freshwater system, nevertheless, its fisheries could be one of many ecosystem services it can provide to society. This study aims to document the main fisheries characteristics of this species during 2014. Many fishing methods were found to capture P. clarkii including trammel nets (Estaquaza and extended nets), gill nets, and traps. About $70 \%$ of the individuals had carapace lengths between 39 and $52 \mathrm{~mm}$ and $95 \%$ the individuals had a mean carapace length that exceeds the harvestable limit $(35 \mathrm{~mm})$. The length-weight relationship data of $P$. clarkii showed an allometric growth for weight more than for length $(b>3)$. The variations in male and female sex ratio with length classes showed that males of $P$. clarkii predominated all length classes except length classes 8 and $12 \mathrm{~cm}$ total length. The results of this study indicate that the crayfish grows considerably longer in the River Nile than it usually does in its original environment and that there is an assisted population, and high yields are expected when crayfish from the River Nile are to be utilized for commercial purposes.

\section{INTRODUCTION}

The red swamp crayfish, Procambarus clarkii (Girard, 1852), is an indigenous species of the South-Central USA and Northeast of Mexico, where the American State Louisiana dominates the world in both natural and aquaculture production of this species (Huner, 1989). This species was introduced to the Egyptian freshwater system for aquaculture in the 1980s at the Giza government then expended in all aquatic systems (streams, ponds, marshes, etc.) whether these environments were clean or polluted which indicates that this species is well adapted in Egyptian environment (Ahmed, 2012).

$P$. clarkii, as an invasive species, has proved to have an adverse impact on the Egyptian freshwater system. It is an aggressive territorial species that dominates and eliminates native predators (Fishar, 2006). It contributes to diminishing invaded ecosystem biodiversity by feeding on fish eggs and fry, worms, insects, snails, crustaceans, amphibians, and small fishes (Ibrahim et al., 1995). It was also reported that P. clarkii attacks adult fishes trapped in nets (Soliman et al., 1998) which causes an 
economic loss for the fisheries sector. Furthermore, its burrowing weakens dam walls, creates leaks in water bodies banks and aquaculture ponds, and increases erosion along watercourses, causing the water to flood the fields (Ahmed, 2012).

On the other hand, some positive aspects of the invasion of this species to the Egyptian freshwaters were reported. P. clarkii has helped in the control of diseases caused by Schistosoma and Fasciola as it feeds on their vector snails. Moreover, $P$. clarkii can be a principal source of food. Depending on size and maturity, the edible abdominal muscles range between $10 \%$ and $40 \%$ of total body weight, (Huner and Barr, 1991). The crayfish muscles contain higher values of protein $(58.6 \mathrm{~g} / 100 \mathrm{~g}$ for females and to $62.6 \mathrm{~g} / 100 \mathrm{~g}$ for males on a dry weight basis) (Huner et al., 1988).

There is a little information about crayfish fisheries biology in the River Nile and its canals despite being extensively distributed in the Egyptian freshwater systems. Most of the studies carried on this species are generally academic and focused on its histology (Sharshar and Geasa, 1998, Garo and Saad, 1999, Sayed, 2002), histopathology (Ramadan, 1997, Abdel Mageed, 2004) and effect of some chemicals on its organs and muscles (Heiba, 1999, Tolba, 1999, Aly, 2000, Hamdi, 2001, Ibrahim et al., 2005). The distribution and quantity of this species are still unknown despite quite old studies and some field observations from fishermen.

One possible strategy for management of the crayfish in the Egyptian freshwater ecosystem is to use it as a resource of animal protein weather for Egyptian people, whom many of them are suffering from malnutrition, or for export. Since there are few studies on $P$. clarkii fisheries biology in Egyptian freshwater ecosystems, and as its exploitation commercially is developing very rapidly, this study aims to document the main fisheries characteristics of this species during 2014, which could be valuable as a baseline for any future studies focuses on its fisheries.

\section{MATERIALS AND METHODS}

A field survey was carried out in June 2014 and covered the River Nile area from the Assiut governorate in the south to the Qalubia government in the north. Fishers were interviewed to collect data on the abundance and distribution of the crayfish in this area, in addition to the fishing methods that were applied to catch them.

174 crayfish were sampled to study its fisheries biology. Total length (TL, from the tip of the rostrum to the tip of telson) was measured to the nearest 0.1 centimetre and carapace length (CL, from tip of the rostrum to posterior margin of the cephalothorax) were measured to the nearest 0.1 millimetre. The animals were weighed (TW, wet weight only of animals with a complete set of chelae) to the nearest 0.1 gram. The animals were sexed. Males were identified by the hooks on the ischia of the third and fourth pereiopods and females were distinguished by the presence of tan, brown and black eggs in the ovary and by the grooved annulus ventralis.

Length-weight relationships were determined according to the equation: $W=\mathrm{aL}^{\mathrm{b}}$ where $\mathrm{W}$ is the weight, $\mathrm{L}$ the total length, $\mathrm{a}$ and $\mathrm{b}$ are constants. These constants were obtained by the logarithmic transformation of the data using a GM Regression (Ricker, 1973): $\log \mathrm{W}=\log \mathrm{a}+\mathrm{b} \log \mathrm{L}$. The value of the constant $b$ will be $3(b=3.0)$ when growth is isometric (Ricker, 1975). The numbers of males and females were recorded to estimate the sex ratio. 


\section{RESULTS}

\section{Abundance and distribution}

This study showed that crayfish of species $P$. clarkii was present in smaller quantities in the south governorates Assiut, Minya, and Beniswaf than that of northward surveyed governorates. They were trapped in nets and baskets as bycatch and in low numbers. They used to be destroyed and discarded by the fishers because they damage nets. Further to the north, in the governorates of Giza and Qalubia, they present in larger amounts. In Ayat in Giza and Bulaq Bridge area in Cairo, traders collect crayfish from fishers, as reported by fishers. Also, it was reported that a special type of nets called "Estaquaza net" was specially made to catch it in the season from April to September.

\section{Fishing methods}

Boats used to catch crayfish are usually made of wood and fitted with paddles. The boat length ranged from 4.25 to 5.5 meters and width ranged from 1.25 to 2.5 meters. Two fishermen exist on each fishing boat. While these boats are used to catch crayfish, they also used to catch other fish species.

Estaquaza net is a type of trammel nets that is specially designed for catching crayfish. Its length ranges between 10 to 20 meters with a height of 1 meter and the meshes size of the outer layers is $5 \mathrm{~cm}$ and of $3 \mathrm{~cm}$ for the inner layer. It is used in areas where water depth ranges between 1.5 to 2 meters. The net is used for the fishing process once a day where it is spread before sunset to dawn the next day (about 12 hours).

Also, extended nets were used to catch crayfish. The length of these nets ranges between 100 and 250 meters with a height from 1 to 1.5 meters and the mesh size of the outer layers ranges between 7 to $20 \mathrm{~cm}$ and the inner layer of 3.5 to $9.6 \mathrm{~cm}$. The crocks used in the floating line are of medium size and distance between each crock and the other ranges between 120 and $150 \mathrm{~cm}$. The lead line is thin with a distance between the lead pieces of 15 to $30 \mathrm{~cm}$. Water depth in fishing areas ranges from 1.5 to 2 meters. The net is used for the fishing process once a day where it is spread before sunset to dawn the next day (about 12 hours). Crayfish present in very low numbers in the catch of these nets where it is made up mostly of tilapia and some other species.

Crayfish are also caught by single-layer nets (gill nets) which consist of a single layer and attach from the top by the floating line and from the bottom by the lead line to ensure the extension of the net horizontally in the water. It often catches tilapia, perch, and a very small number of crayfish. The length of the net is 20 meters with a height of 3 meters and mesh size ranging from $3 \mathrm{~cm}$ to $5 \mathrm{~cm}$. The distance between lead pieces is about 1 meter and it is of medium size. The floating line has small size crocks and the distance between each crock and the other is about $20 \mathrm{~cm}$. The net is used for the fishing process once a day where it is spread before sunset to dawn the next day (about 12 hours) at depth of water of about 5 meters. Round baskets were also used to catch crayfish in River Nile. It is made of a steel wire with two large holes on the top and the bottom, and a smaller hole in the middle. It is placed next to the grass near the banks or on the stony bottoms. Species caught beside crayfish are tilapia and other species. The size of the large holes is ranging between 15 and $40 \mathrm{~cm}$ and the smaller hole from 10 to $15 \mathrm{~cm}$. The mesh size is ranging from 4 to $5 \mathrm{~cm}$ and uses two canes on both sides to open the inner aperture. Traps are placed in the water in the afternoon to dawn in depth ranges from 1.5 to 2 meters. 


\section{Population structure}

The carapace lengths (CL) of the crayfish sample studied $(n=174)$ ranged from 29.3 to $67.6 \mathrm{~mm}$, and $70 \%$ of the individuals had carapace lengths between 39 and $52 \mathrm{~mm}$. (Fig. 1). The modal classes were $51 \mathrm{~mm} \mathrm{CL}$ for males $(\mathrm{n}=103)$ and $44 \mathrm{~mm}$ CL for females $(n=71)$ and $95 \%$ of the population had $>35 \mathrm{~mm}$. The individuals of both sexes had a mean carapace length (47.2 $\mathrm{mm}$ for males and $47.8 \mathrm{~mm}$ for females) that exceed the harvestable limit. The largest male captured was $68 \mathrm{~mm}$ CL while the largest females measured $65 \mathrm{~mm}$ CL. Length-frequency data of the sample were arranged in one $\mathrm{cm}$ intervals for TL and one $\mathrm{mm}$ intervals for CL and the results are graphically represented in figures 2 and 3. From these figures, it is clear that the majority of animals were in the length groups around their average length while the terminal length groups were represented by the lowest percentage of the catch.

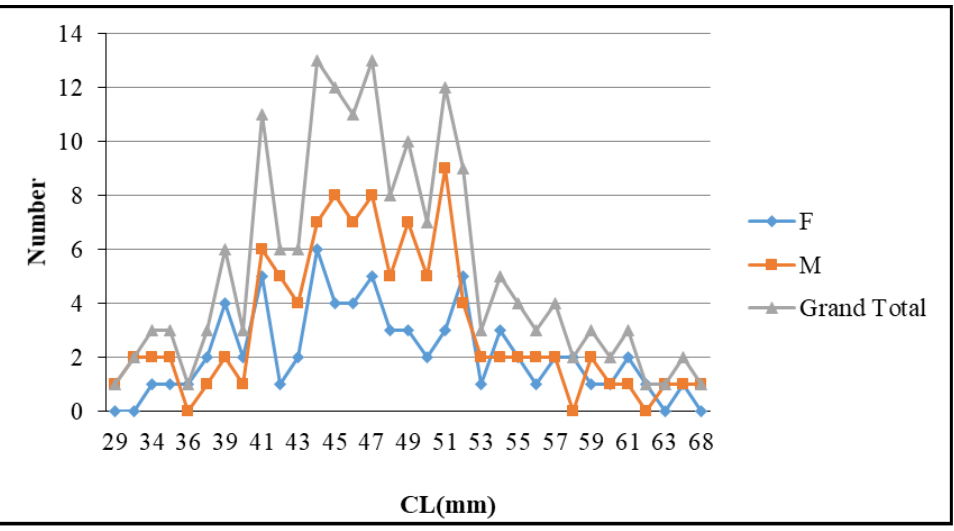

Fig. 1: Fluctuations of females, males and total numbers of P. clarkii with the carapace lengths (CL)

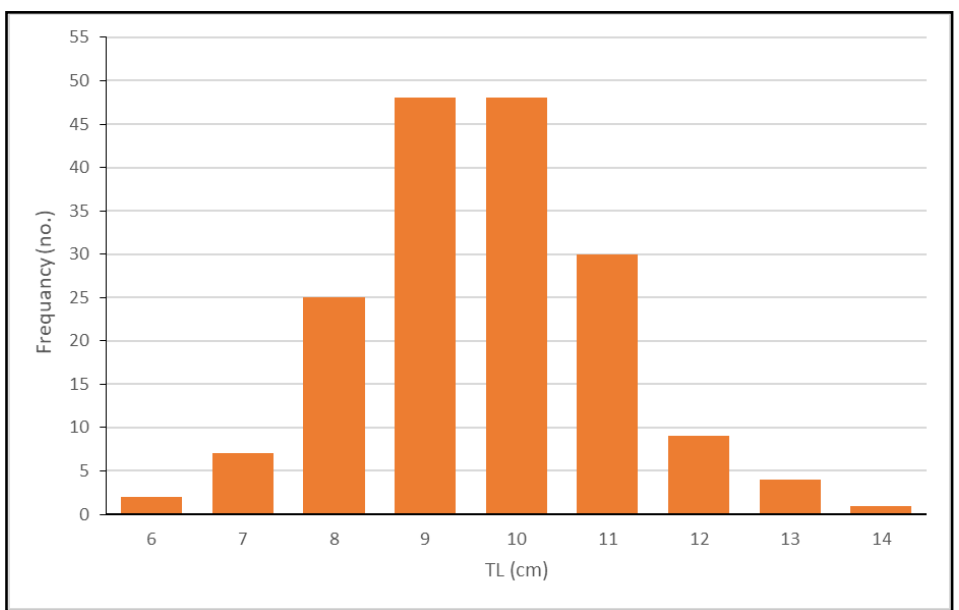

Fig. 2: Length-frequency of $P$. clarkii for total length. 


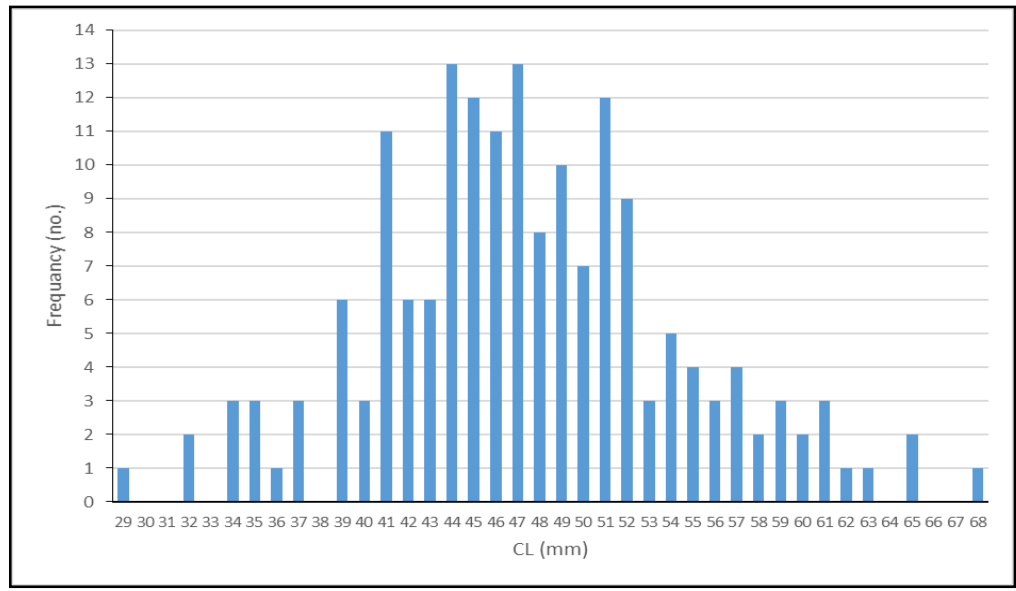

Fig. 3: Length-frequency of $P$. clarkii for carapace length.

\section{Length-weight relationship}

Knowledge of length-weight relationship provides mathematical expression between these two measurements hence one could be converted to the other which makes it an important biological tool in the management of fisheries. The length-weight relationships were calculated for $P$. clarkii using both total length (TL) and carapace length (CL) data. The results are presented in figures 4 and 5, and the relationship parameters are given also. The values of the constant " $b$ " in all of the above regressions were more than three therefore $P$. clarkii shows an allometric growth for weight more than for length $(b>3)$.

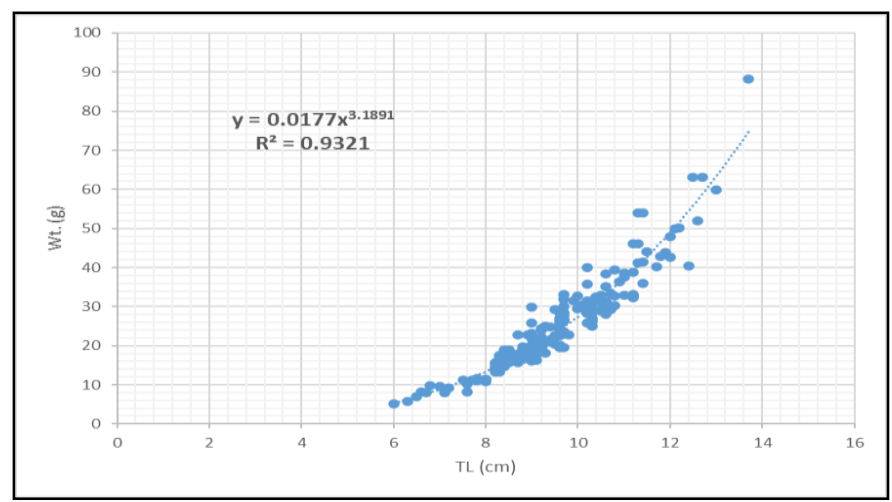

Fig. 4: Length-weight relationship of P. clarkii using total length.

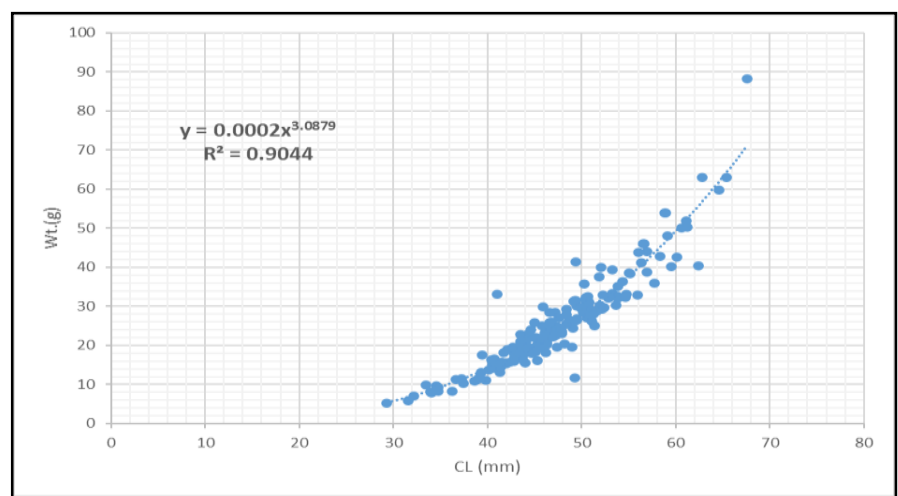

Fig. 5: Length-weight relationship of $P$. clarkii using carapace length. 


\section{Sex ratio}

The sex ratio of the collected samples was 1: 0.69. The Chi square and Fisher's exact test were applied and the difference between calculated 1: 0.69 and theoretical 1: 1 ratio was found to be significant at the level alpha $=0.05$. Variations in male and female sex ratio with length classes showed that males of $P$. clarkii predominated all length classes except length classes 8 and $12 \mathrm{~cm}$ TL (Fig. 6).

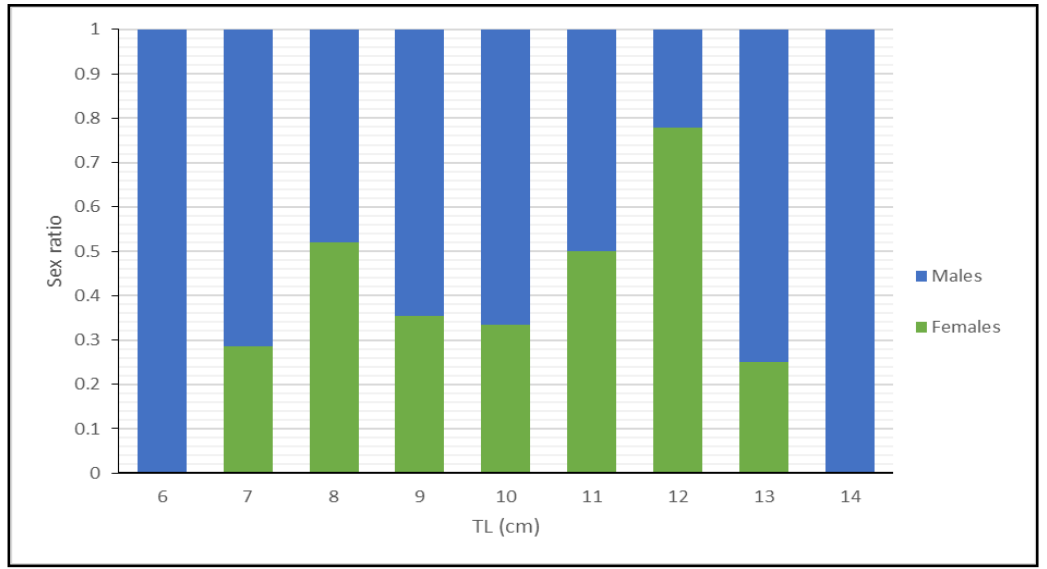

Fig. 6: Variations in the sex-ratio of P. clarkii with different length classes.

\section{DISCUSSION}

Fisheries is one of many ecosystem services that could be provided to society by crayfish in Egyptian freshwater ecosystems. This species could be a valuable target of the subsistence and artisanal fisheries practiced by rural poor people to provide them with an essential source of supplemental income. This valuable resource is threatened by the lack of a research-based understanding of its fisheries characteristics and dynamics in such a new environment. Since there are few studies on crayfish fisheries practices in River Nile and its canals, the results of the current study are very important to understand some of the main characteristics of crayfish fisheries biology in River Nile.

Previous studies indicate that two species of crayfish were introduced to the Egyptian aquatic ecosystem, $P$. clarkii and $P$. zonangulus (Fishar, 2006). During this study period, $P$. clarkii quantities were decreasing southwardly from Giza to Assiut while $P$. zonangulus was completely disappeared in the surveyed localities. P. clarkii was recorded in the Delta region, Cairo, and Giza Governorates by Hamdi (1994). Ibrahim et al. (1996) surveyed P. clarkii along the River Nile and its main tributaries from Qena to the Nile outlet on the Mediterranean Sea. They stated that the two species of crayfish, $P$. clarkii and $P$. zonangulus, were found to be thoroughly distributed and have already established viable populations in the freshwater ecosystem of Cairo, Giza and some Nile Delta Governorates while they were not recorded in the Nile southward at Upper Egypt at that time. They also reported that, $P$. clarkii indicated remarkable predominance over $P$. zonangulus in spite of that the two species coexist in mixed populations throughout most of the examined areas. According to that study, the central governorates (Qalubia, Cairo and Giza) were variably populated with high density of crayfish then this high density decreased gradually northward (El-Menoufiya and El-Sharkiya governorates) and southward (Aiat and Babha cities).In the Giza governorate, crayfish were found 
frequently in all watercourses including the Nile, Ibrahimia Canal, and their emerged canals (Nahia, Warrak El-Arab, Abou-Rawash region, El-Zumur, and El- Marouteya canals). Soon, it was reported that P.clarkii had been already invaded most of the governorates of Upper and Lower Egypt and its distribution had extended from northern Delta to Assiut (Ibrahim et al., 1997). Later, Soliman et al. (1998) studied the distribution of P.clarkii and revealed that this species colonized Cairo, Giza, and Delta waters. Though the crayfish were widely distributed in the Egyptian freshwater ecosystem, their growth rates were not varied from locality to another (Mubarak, 1996).

The length-weight relationship analysis showed non-isometric (allometric) growth for P. clarkii in River Nile. Romaire et al. (1977), Correia (1993) reported similar results for Louisiana (USA) and Portuguese crayfish populations, respectively. In River Nile, Saad et al. (2015) used the total length to calculate the length-weight constants for samples collected from two sites in Qalubia and Cairo. They reported $b$ values of 3.1910, 3.0999, and 3.0804 for males, females, and combined sexes respectively which consensus with the results of the present study.

The size structure of a population is useful in predicting its stunting and harvestable potential (Momot and Romaire, 1981). In this study, P. clarkii specimens collected from River Nile had a maximum TL equal to $13.7 \mathrm{~cm}$ with a weight of over $88 \mathrm{~g}$, and carapace lengths (CL) ranged between 29.3 and $67.6 \mathrm{~mm}$. Ibrahim et al. (1995) divided the size groups of $P$. clarkii in River Nile to very young stages $(0.5-0.9 \mathrm{~cm}$ carapace length), medium-sized crayfish $(2.0-4.9 \mathrm{~cm}$ carapace length), and large-sized individuals (over $5 \mathrm{~cm}$ carapace length). The very young stages were not recorded in the current study. Huner and Romaire (1978) studied P. clarkii populations in stable deep waters from the Atchafalaya basin in Louisiana and found that body size was directly influenced by habitat quality. They indicated that stable habitat conditions, combined with low population densities, produced large crayfish, ranging from $8.4 \mathrm{~cm}$ TL $(\sim 18 \mathrm{~g})$ to 13.5 $\mathrm{cm}$ TL ( $~ 84 \mathrm{~g})$. In River Nile, Saad et al. (2015) reported that $P$. clarkii ranged between 7 and $13.8 \mathrm{~cm}$ TL $(3.5-7.4 \mathrm{~cm} \mathrm{CL})$ for males and between 7 and $15 \mathrm{~cm}$ TL $(3.5-8 \mathrm{~cm}$ CL) for females. The comparison of the results of the current study with the published data indicates that $P$. clarkii in River Nile grows longer than in many other locations. Correia and Costa (1994) reported that no individuals of wild populations studied by Penn Jr (1943) in Louisiana exceeded $11.6 \mathrm{~cm}$ TL and $47 \mathrm{~g}$ body weight. In Doňana National Park (SW Spain) and Săo Miguel (Azores, Portugal), P. clarkii did not exceed $10.5 \mathrm{~cm}$ and $9.86 \mathrm{~cm}$ in total body length, respectively (Bravo et al., 1994, Costa et al., 1996). Therefore, it appears that $P$. clarkii lives considerably longer and /or grow better in River Nile than it usually does in its original habitats where most males die at the end of their first year, and females rarely exceed two-year-old (Penn Jr, 1943, Huner, 1988, Bravo et al., 1994). Frutiger et al. (1999) found that in a eutrophic pond in Switzerland (with stable habitat conditions) $P$. clarkii could even grow up to five years. The lengthfrequency data of $P$. clarkii in the present study showed that $95 \%$ of the total population were larger than the minimal acceptable harvestable size of 35mm CL (Romaire and Lutz, 1989). This may indicate the presence of an assisted population, and high yields should be expected when crayfish from the River Nile were utilized for commercial purposes. Emam and Khalil (1995) estimated the average annual yield of P. clarkii in the River Nile to be about 4.6 tonnes/ year. Their results indicate that the stock of $P$. clarkii is so far under exploitation at that time. They also noted that the yield per recruit and the 
age of the first capture by using traps were higher than that by using nets, therefore, using traps as a fishing gear for crayfish will help and save the biomass per recruit rather than using nets.

The sex ratio around 1:1 ratio was reported by many authors (Penn Jr, 1943, Huner, 1978), however, Correia and Costa (1994) studied P. Clarkii in Sao Miguel, Azores, Portugal and they reported that sex ratio varies with seasons where females were less abundant in the months with maximum ovarian egg maturation which agrees with the results of current study where males of $P$. clarkii predominated most length classes (1; 0.69). Frutiger et al. (1999) in their study of $P$. Clarkii in a small eutrophic pond in Switzerland, explained the decrease of female numbers by that most of the mature females became ovigerous in some seasons and thus stayed in their borrows (Bravo et al., 1994, Frutiger et al., 1999). This is could be also explained by the reproductive behaviour of $P$. clarkii; where low numbers of females in samples could correspond with high numbers of ovigerous females that are difficult to catch.

\section{CONCLUSION}

This study documents some biological characteristics of $P$. clarkii in River Nile during 2014. The abundance of this species was increasing gradually southward and it started to be recorded in Upper Egypt governorates with more quantities than that recorded in previous studies. The results of this study indicate that the crayfish grows considerably longer in River Nile than it usually does in its original environment and that there is an assisted population, and high yields are expected when crayfish from the River Nile are to be utilized for commercial purposes.

\section{ACKNOWLEDGMENT}

This study is a part of the project "Crayfish, from problem to solution" that was funded by the National Institute of Oceanography and Fisheries, Egypt.

\section{REFERENCES}

Abdel Mageed, Z. A. Y. (2004). Biochemical and biological studies on Procambarus clarkii (Girard, 1852), from Egypt. Ph. D. , Helwan University.

Ahmed, K. A. (2012). Ecological studies on crayfish, Procambarus clarkii (Girard, 1852) in some sectors of the River Nile and its tributaries in Egypt. M.Sc., Ain Shams University.

Aly, R. H. (2000). Effect of natural and chemical insecticides on some organs of the female crayfish, Procambarus clarkii (Crustacea: Decapoda) from the River Nile, Egypt. Egypt. J. Aquat. Biol. Fish 4(4): 83-103.

Bravo, M. A. ; Duarte, C. M. and Montes, C. (1994). Environmental factors controlling the life history of Procambarus clarkii (Decapoda, Cambaridae) in a temporary marsh of the Doñana National Park (SW Spain). Internationale Vereinigung für theoretische und angewandte Limnologie: Verhandlungen 25(4): 2450-2453.

Correia, A. M. and Costa, A. C. (1994). Introduction of the red swamp crayfish, Procambarus clarkii (Crustacea: Decapoda) in São Miguel, Azores, Portugal. ARQUIPÉLAGO. Ciências Biológicas e Marinhas= Life and Marine Sciences 12: 67-73. 
Correia, M. (1993). Length-weight relationships for two populations of red swamp crayfish, Procambarus clarkii (Decapoda, Cambaridae) from Portugal. University of Southwestern Louisiana, Lafayette, LA(USA). 442-450.

Costa, A. C. ; Correia, A. M. and Rodrigues, M. L. (1996). Monitoring a population of Procambarus clarkii (Decapoda, Cambaridae) in Sào Miguel (Azores, Portugal). Freshwater crayfish 11: 203-212.

Emam, W. M. and Khalil, M. T. (1995). Population dynamics and stock assessment of the newly introduced crayfish Procambarus clarkii in the River Nile, Egypt. Proc. Zool. Soc. AR Egypt 26: 131-143.

Fishar, D. M. R. (2006). Red swamp crayfish (Procambarus clarkii) in River Nile, Egypt. Biodiversity Monitoring and Assessment Project. Cairo, Ministry of State for Egyptian Environmental Affairs Agency.

Frutiger, A. ; Borner, S. ; Büsser, T. ; Eggen, R. ; Müller, R. ; Müller, S. and Wasmer, H. R. (1999). How to control unwanted populations of Procambarus clarkii in Central Europe. Freshwater Crayfish 12: 714-726.

Garo, K. and Saad, A. H. (1999). Ultrastructural characterization of hematocystes and phagocytes in the hepatopanreas of the crayfish Procambarus clarkii. Journal of Union of Arab Biologists 12: 413-430.

Hamdi, S. A. H. (1994). Studies on the red swamp crayfish Procambarus clarkii (Girard, 1852)(Decapoda: Camrbaridae) in the River Nile, Egypt. M. Sc. Thesis, , Cairo University.

Hamdi, S. A. H. (2001). Biological studies on the red swamp crawfish Procambarus clarkii (Girard, 1852) (Decapda: Camaridae) in the River Nile, Egypt. Ph.D., Cairo University.

Heiba, F. (1999). Effects of the Insecticide, Diazinon on the Hepatopancreas of the Freshwater Crayfish Procambarus clarkii. Egyptian Journal of Aquatic Biology and Fisheries 3(2): 197213.

Huner, J. V. (1978). Crawfish population dynamics as they affect production in several small, open commercial crawfish ponds in Louisiana, Wiley Online Library.

Huner, J. V. (1988). Procambarus in North America and elsewhere. Freshwater crayfish: biology, management and exploitation.: 239-261.

Huner, J. V. (1989). Overview of international and domestic freshwater crawfish production. Journal of Shellfish Research 8(1): 259-265.

Huner, J. V. and Barr, J. E. (1991). Red Swamp Crawfish: Biology and Exploitation; Louisiana Sea Grant College Program, Center for Wetland Resources, Lousiana State Univ.

Huner, J. V. ; Lindqvist, O. V. and Könönen, H. (1988). Comparison of morphology and edible tissues of two important commercial crayfishes, the noble crayfish, Astacus astacus Linné, and the red swamp crayfish, Procambarus clarkii (Girard)(Decapoda, Astacidae and Cambaridae). Aquaculture 68(1): 45-57.

Huner, J. V. and Romaire, R. P. (1978). Size at maturity as a means of comparing populations of Procambarus clarkii (Girard)(Crustacea, Decapoda) from different habitats. Freshwater Crayfish 4: 53-64.

Ibrahim, A. M. ; Emam, W. M. and Abdel-Rahman, S. (2005). Ridding of undesirable crayfish Procambarus clarkii from certain habitat in Egypt by means of organophosphorus insecticide. J Egypt Acad Soc Environ Dev 6(2): 267e276.

Ibrahim, A. M. ; Khalil, M. T. and Mobarak, F. M. (1995). On the feeding behavior of the exotic crayfish Procambarus clarkii in Egypt and its prospects in the biocontrol of local vector snails. Journal Union Arabian Biology Cairo 4: 321-340.

Ibrahim, A. M. ; Khalil, M. T. and Mubarak, M. F. (1996). Ecological studies on the exotic crayfishes Procambarus clarkii (Girard 1852) and P. zoangulus Hobbs \& Hobbs 1990, in the River Nile Egypt. Journal-Egyptian German Society of Zoology 20: 167-186. 
Ibrahim, A. M. ; Khalil, M. T. and Mubark, M. F. (1997). Ecological studies on the exotic Crayfishes Procambarus clarkii and Procambarus zonangulus in the River Nile. Int. J. Ecol. Environ. Sci 23: 217-228.

Momot, W. T. and Romaire, R. P. (1981). Use of A Seine to Detect Stunted Crawfish Populations In Ponds, A Preliminary Report 1. Journal of the World Mariculture Society 12(2): 384-390.

Mubarak, M. F. (1996). Ecological studies on the newly introduced freshwater crayfish, P. clarkii and its impact upon the diversity of zooplankton and bottom fauna in the River Nile, Egypt. M.Sc. , Ain Shams University.

Penn Jr, G. H. (1943). A study of the life history of the Louisiana red crawfish, Cambarus clarkii Girard. Ecology 24(1): 1-18.

Ramadan, N. (1997). A study on some Protozoa infesting the freshwater crayfish, Procambarus clarkii in Egypt. Egyptian Journal of Aquatic Biology and Fisheries 1(2): 359-377.

Ricker, W. E. (1973). Linear regressions in fishery research. Journal of the fisheries board of Canada 30(3): 409-434.

Ricker, W. E. (1975). Computation and interpretation of biological statistics of fish populations. Bull. Fish. Res. Bd. Can. 191: 1-382.

Romaire, R. P. ; Forester, J. S. and Avault, J. V. (1977). Length-weight relationships of two commercially important crayfishes of the genus Procambarus. Freshwater Crayfish 3: 463470.

Romaire, R. P. and Lutz, C. G. (1989). Population dynamics of Procambarus clarkii (Girard) and Procambarus acutus acutus (Girard)(Decapoda: Cambaridae) in commercial ponds. Aquaculture 81(3-4): 253-274.

Saad, A. E.-H. ; Mehanna, S. ; Khalil, M. and Said, M. (2015). Population dynamics of the freshwater crayfish Procambarus clarkii (Girard, 1852) in the River Nile, Egypt. Egyptian Journal of Aquatic Biology and Fisheries 19(2): 101-116.

Sayed, M. M. (2002). Biological studies on the crayfish Procambarus clarkii in the river Nile. M. sc., Ain Shams university. .

Sharshar, K. M. and Geasa, N. M. S. (1998). Effect of Copper on hemocytes in the crayfish, Procambarus clarkii (Crustacea, Decapoda). Egypt. J. Aquat. Fish 2(4): 1-13.

Soliman, G. N. ; El-Assal, F. ; El-Deen, M. S. and Hamdi, S. A. H. (1998). The reproductive biology of the red swamp crayfish P. clarkii (Girard, 1852)(Decapoda: Cambridae) in the River Nile, Egypt. Egypt. Journal of Zoology 30: 311-325.

Soliman, G. N. ; El-Assal, F. ; Salah El-Deen, M. and Hamdi, S. A. (1998). Habitat, distribution and behaviour of the red swamp crawfish Procambarus clarkii (Girard, 1852)(Decapoda: Cambridae) in the River Nile, Egypt. Journal of Zoology 30: 297-310.

Tolba, M. R. (1999). The red swamp crayfish Procambarus clarkii (Decapoda: Cambaridae) as bio-indicator for total water quality including $\mathrm{Cu}$ and $\mathrm{Pb}$ pollution. Egypt. J. Aquat. Biol. Fish 3(1): 59-71. 